\title{
Editorial: corals, reefs and marine biodiversity
}

\author{
Bert W. Hoeksema • Sancia E. T. van der Meij
}

Received: 11 January 2013 / Accepted: 16 January 2013 / Published online: 29 January 2013

(C) Senckenberg Gesellschaft für Naturforschung and Springer-Verlag Berlin Heidelberg 2013

\section{2nd World Conference on Marine Biodiversity}

This issue of Marine Biodiversity contains a selection of papers that were presented as a talk or digital object during the session "Biodiversity of Coral Reefs" at the 2nd World Conference on Marine Biodiversity in Aberdeen (26-30 September, 2011). During the 1st World Conference on Marine Biodiversity in Valencia (11-15 November, 2008) a similar session on coral reefs was organized: "The Coral Triangle: patterns and processes in marine species richness and habitat diversity" (Miloslavich and Klein 2009). Coral reefs are well-known for their high biodiversity (Paulay 1997; Bouchet 2006; Hoeksema 2007), and therefore it was clear that sessions on biodiversity of coral reefs were apt for these conferences.

For the session "Biodiversity of Coral Reefs" a total of 23 oral presentations and 16 digital objects was accepted. The participants who presented their research came from various countries around the world: Australia (4), Bangladesh, Colombia, France, Greece, India (4), Indonesia (2), Iran, Italy (3), Japan (3), Mexico, the Netherlands (2), Norway, Oman, Portugal (2), Thailand (2), the United Kingdom (4), and the United States of America (5). The research on which they reported concerned corals and reefs in various parts of the world: Indo West-Pacific (19), W Atlantic / Caribbean (5), Mediterranean (4), E Atlantic (2), general/global (9).

\section{Topics on corals and coral reefs in the journal marine biodiversity}

\section{History}

Marine Biodiversity is a continuation of Senckenbergiana maritima, which was published between 1969 and 2008

B. W. Hoeksema $(\bowtie) \cdot$ S. E. T. van der Meij

Department of Marine Zoology, Naturalis Biodiversity Center,

Darwinweg 2, 2333 CR Leiden, The Netherlands

e-mail: bert.hoeksema@naturalis.nl
(Volumes 1-38). Senckenbergiana maritima published papers on all aspects of marine sciences, in particular on marine biology, palaeontology, geochemistry, oceanography, geology and sedimentology. This 'International Journal of Marine Sciences' was published by the Senckenberg Gesellschaft für Naturforschung, Frankfurt am Main (Germany), and had two sister journals, Senckenbergiana lethaea with articles on palaeontology and geology, and Senckenbergiana biologica with contributions on zoology and botany. All three Senckenbergiana titles ceased publication in December 2008.

As successor of Senckenbergiana maritima, Marine Biodiversity started in 2009 with Vol. 39, devoted to all aspects of biodiversity research in marine ecosystems. It encourages contributions dealing with the understanding of the evolution and maintenance of biodiversity in marine systems and the role of species in structuring marine ecosystem functioning. In comparison to its predecessor, Marine Biodiversity appears to be less oriented toward Western Europe and has become more of a global forum, which is illustrated by the increasing frequency of papers on corals and coral reefs in the last years (Fig. 1).

Various special volumes and issues in the past concerned geographical areas where corals and coral reefs do not occur: Vol. 4 Georgia coastal region, Sapelo Island, U.S.A.: sedimentology and biology; Vol. 7 Estuaries of the Georgia coast, U.S.A.: sedimentology and biology; Vol. 16 (1-6) Experimental investigations about effects of crude oil and dispersed crude oil in tidal flat environments; Vol. 24 (1-6) Tidal flats and barrier systems of continental Europe; Vol. 27 (3-6) Workshop of the Ecosystem Research Wadden Sea; Vol. 29 (1-6) 9th International Scientific Wadden Sea Symposium; Vol. 31 (2) 14th International Senckenberg Conference on Burning Issues of North Sea Ecology; Vol. 33 (1-2) North Sea 2000 (I): state of the art in marine biology at the end of the 20th century; Vol. 34 (1) North Sea 2000 (II): state of the art in environmental parameters at the end of the 20th century; Vol. 39 (3) The Atlántida 2008 Cave Diving Expedition; Vol. 41 (1) Arctic Ocean 


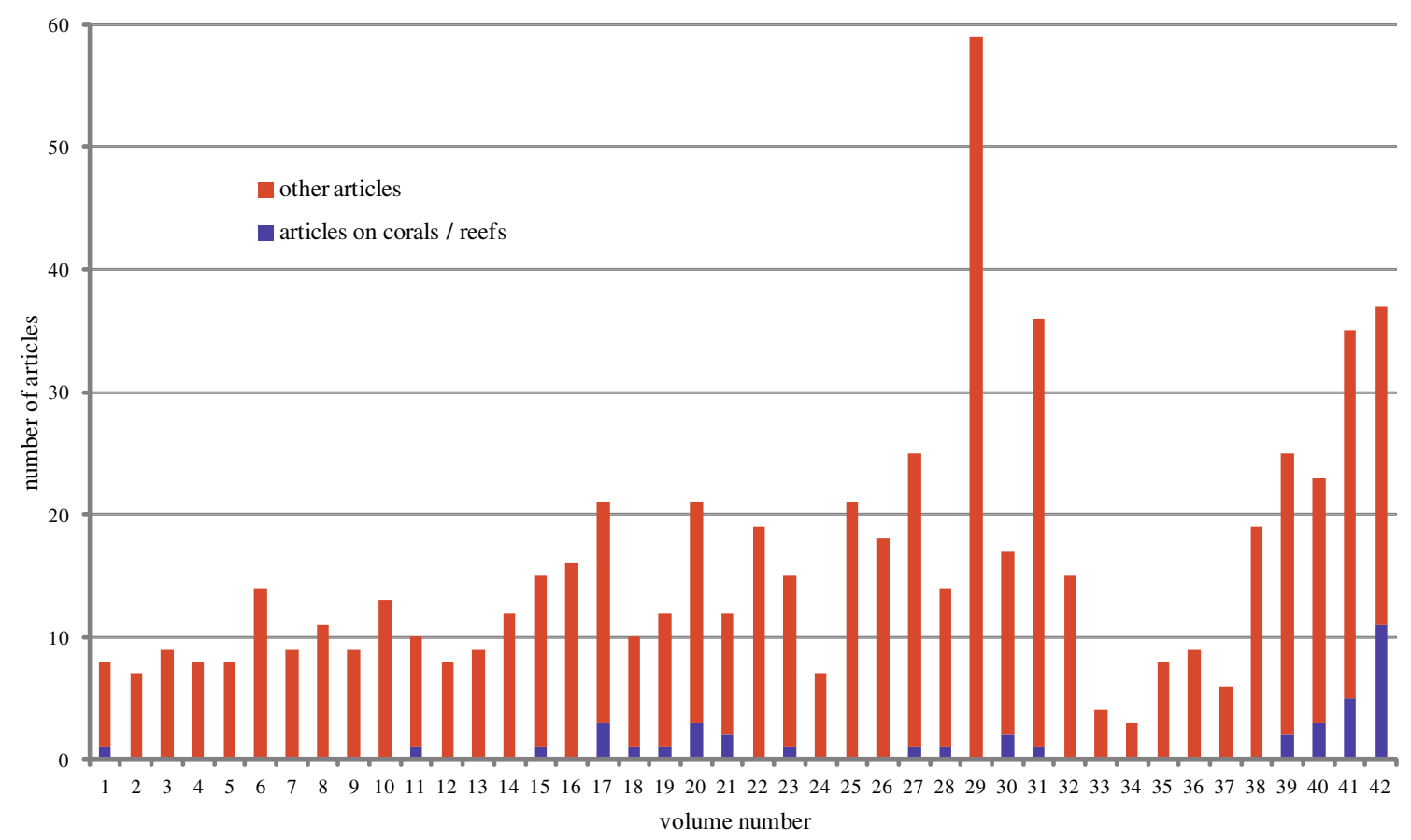

Fig. 1 Volumes 1-42 (1969-2012) of Senckenbergiana maritima (1-38) and its successor Marine Biodiversity (39-42), with total numbers of articles and particularly those dedicated to corals or coral reefs

Diversity: Synthesis; and Vol. 41 (3) Arctic Marine Biodiversity under Change.

It is obvious that the number of coral-related articles will be relatively high in the current Vol. 43, particularly thanks to the present special issue. Articles published and in press in both journals (1969-present) are categorized according to taxon, topic, and geographical area (Tables 1,2 and 3).

\section{Taxa}

Cnidaria (Coelenterata) constitute the most common subject in articles on coral reef biodiversity in Marine Biodiversity and Senckenbergiana maritima (Table 1). This is noteworthy because stony corals (Scleractinia) consist of only $\sim 1,500$ globally described species, soft corals and gorgonians (Octocorallia) of $\sim 3,200$, and stylasterids of $\sim 250$, out of a total of $\sim 225,000$ known marine species worldwide (Appeltans et al. 2012). Crustaceans $(\sim 50,000)$, molluscs $(\sim 47,500)$ and fish $(\sim 17,500)$, which together comprise $\sim 50 \%$ of all known marine species (Costello et al. 2010; Appeltans et al. 2012), rank lower in frequency (Table 1). Scleractinians receive much attention, particularly the zooxanthellate and reef-building species in shallow water. In the long term, many of the shallow-water corals are threatened with extinction (Carpenter et al. 2008). The azooxanthellate scleractinians (about $50 \%$ of all species) are less easily studied because many of them occur in deep water (Cairns et al. 1999; Cairns and Kitahara 2012). These deep-water corals may be threatened as well (Miller et al. 2009;
Santodomingo et al. 2013), but this may well be less detectable than in shallow-water reef corals. For the latter, baseline data from museum collections can be obtained relatively easily (van der Meij et al. 2010; Hoeksema et al. 2011) as well as detailed distribution data from marine biodiversity databases, such as the World Register of Marine Species (WoRMS, see Costello et al. 2013).

Coelenterates are important as reef-builders and as habitat and food for other organisms, but they do not have special journals dedicated to them, such as the species-rich molluscs (e.g. Journal of Molluscan Studies, Molluscan Research, Nautilus, Malacologia) and crustaceans (Crustaceana and Journal of Crustacean Biology). The journal Coral Reefs deals with various kinds of reef studies, but does not have an outspoken preference for articles on corals. Marine Biodiversity shows much emphasis on taxonomy while covering research at gene, species and ecosystem level as well as focusing on describing the actors (genes and species), the patterns (gradients and distributions) and understanding of the processes responsible for the regulation and maintenance of diversity in marine systems. Also included are studies of species interactions (symbioses, parasitism, predation) and the role of species in structuring marine ecosystem functioning.

Topics

It is obvious that corals, which host many other organisms and therefore play an important role in species-rich coral 
Table 1 Taxa ranked according to frequency of their representation in articles dealing with corals or reefs in the journal Marine Biodiversity and its predecessor Senckenbergiana maritima (1969-present)

Cnidaria, Coelentera (28): Grasshoff (1979, 1985, 1989), Grasshoff and Zibrowius (1983), Türkay and Schuhmacher (1985), Kleemann (1986, 1990), Lawniczak (1987), Dullo and Hecht (1990), Heiss et al. (1993), Fabricius (1996), Heiss et al. (1999), Camillo et al. (2011), GarcíaMatucheski and Muniain (2011), Reimer et al. (2011), Aharonovich and Benayahu (2012), Carranza et al. (2012), Grossowicz and Benayahu (2012), Hoeksema (2012), Hoeksema and Waheed (2012), van der Meij and Reijnen (2012), Davies et al. (2013), Kamezaki et al. (2013), Ohara et al. (2013), Santodomingo et al. (2013), van der Meij and Hoeksema (2013), Waheed and Hoeksema (2013), Yeemin et al. (2013)

Mollusca (7): Kleemann (1986, 1990), García-Matucheski and Muniain (2011), Harrison and Smith (2012), Hui et al. (2012), van der Meij and Reijnen (2012), Chavanich et al. (2013)

Crustacea (6): Türkay and Schuhmacher (1985), Senn and Glasstetter (1989), Burukovsky (2000), White (2012, 2013), van der Meij and Hoeksema (2013)

Chordata, Vertebrata, Pisces (4): Fishelson (1989), Uiblein et al. (1998), Malcolm et al. (2010), Ahmadia et al. (2012)

Unspecified / general (4): Schäfer (1969), Barnes et al. (2009), Miloslavich and Klein (2009), Alexander et al. (2011)

Plantae (3): Reimer et al. (2010, 2011), Kamezaki et al. (2013)

Porifera (3): Schönberg (2000, 2001), Aguilar and Reimer (2010)

Chordata, Ascidia (2): Hoeksema and Waheed (2012), Shenkar (2012)

Echinodermata (2): Fabricius (1996), Alvarado (2011)

Bryozoa (1): Bijma and Boekschoten (1985)

reefs (Paulay 1997; Stella et al. 2011; Hoeksema et al. 2012), should constitute an important topic in Marine Biodiversity. Nevertheless, symbionts in marine ecosystems are vastly undersampled and understudied (Bouchet 2006). This is also visible in the present overview. Among major topics of coral-related research, the category "Trophic and other interspecific relations" is ranking only fourth after topics related to morphology, distribution patterns and taxonomy (Table 2). Nevertheless, Marine Biodiversity welcomes reports on species interactions.

\section{Geography}

Another interesting analysis concerns the geographical areas where the reported coral and coral reef studies were carried out (Table 3). The Indo-Pacific is well known for its rich coral diversity, especially the central part at the Indo-Pacific convergence, which applies to both deep-water and shallowwater corals (Cairns 2007; Hoeksema 2007). This is also reflected in the numbers of studies from that area as compared to the Atlantic (Table 3). Research on corals and coral reefs in the East Atlantic and in the East Pacific so far appears to be underrepresented in Marine Biodiversity, which hopefully will change in the future.

\section{The conference papers}

This special issue is composed of six coral and reef-related research papers, dealing with a variety of topics. In line with

Table 2 Topics ranked according to frequency of their representation in articles dealing with corals or reefs in the journal Marine Biodiversity and its predecessor Senckenbergiana maritima (1969-present)

Morphology, growth and physiology (16): Schäfer (1969), Grasshoff (1979), Grasshoff and Zibrowius (1983), Bijma and Boekschoten (1985), Kleemann (1986), Lawniczak (1987), Fishelson (1989), Dullo and Hecht (1990), Heiss et al. (1993), Uiblein et al. (1998), Heiss et al. (1999), Schönberg (2001), Aharonovich and Benayahu (2012), Grossowicz and Benayahu (2012), Hoeksema (2012), Kamezaki et al. (2013)

Regional and temporal distribution and diversity patterns (16): Grasshoff (1979), Grasshoff and Zibrowius (1983), Senn and Glasstetter (1989), Barnes et al. (2009), Malcolm et al. (2010), Alvarado (2011), Ahmadia et al. (2012), Carranza et al. (2012), Harrison and Smith (2012), White (2012), Chavanich et al. (2013), Ohara et al. (2013), Santodomingo et al. (2013), van der Meij and Hoeksema (2013), Waheed and Hoeksema (2013), Yeemin et al. (2013)

Taxonomy, phylogeny, genetics (13): Grasshoff (1985, 1989), Senn and Glasstetter (1989), Burukovsky (2000), Schönberg (2000), Aguilar and Reimer (2010), Reimer et al. (2010), Camillo et al. (2011), Aharonovich and Benayahu (2012), Hui et al. (2012), Shenkar (2012), Chavanich et al. (2013), Davies et al. (2013)

Trophic and other interspecific relations (10): Türkay and Schuhmacher (1985), Kleemann (1986, 1990), Fabricius (1996), Reimer et al. (2010, 2011), García-Matucheski and Muniain (2011), Hoeksema and Waheed (2012), van der Meij and Reijnen (2012), van der Meij and Hoeksema (2013)

Marine biodiversity general (2): Miloslavich and Klein (2009), Alexander et al. (2011)

Methodology (2): Aharonovich and Benayahu (2012), White (2013) 
Table 3 Geographic areas ranked according to frequency of their representation in articles dealing with corals or reefs in the journal Marine Biodiversity and its predecessor Senckenbergiana maritima (1969-present)

Indo-Pacific (35): Schäfer (1969), Türkay and Schuhmacher (1985), Kleemann (1986, 1990), Senn and Glasstetter (1989), Fishelson (1989), Dullo and Hecht (1990), Heiss et al. (1993), Fabricius (1996), Uiblein et al. (1998), Heiss et al. (1999), Burukovsky (2000), Schönberg (2000, 2001), Barnes et al. (2009), Aguilar and Reimer (2010), Malcolm et al. (2010), Reimer et al. (2010, 2011), Camillo et al. (2011), Aharonovich and Benayahu (2012), Ahmadia et al. (2012), Grossowicz and Benayahu (2012), Harrison and Smith (2012), Hoeksema and Waheed (2012), Hui et al. (2012), Shenkar (2012), van der Meij and Reijnen (2012), White (2012), Chavanich et al. (2013), Kamezaki et al. (2013), Ohara et al. (2013), van der Meij and Hoeksema (2013), Waheed and Hoeksema (2013), Yeemin et al. (2013)

Atlantic (13): Grasshoff and Zibrowius (1983), Bijma and Boekschoten (1985), Grasshoff (1985, 1989), Kleemann (1986), Lawniczak (1987), Kleemann (1990), Alvarado (2011), García-Matucheski and Muniain (2011), Carranza et al. (2012), Hoeksema (2012), Davies et al. (2013), Santodomingo et al. (2013)

Worldwide (5): Grasshoff (1979), Fishelson (1989), Miloslavich and Klein (2009), Alexander et al. (2011), White (2013)

the trend observed in the previous volumes of Marine Biodiversity (Table 1), Cnidaria / Coelenterata form the most frequently represented taxa.

Santodomingo et al. (2013) present an updated overview of the distribution and diversity of azooxanthellate corals (hard corals, soft corals and black corals) in the Colombian Caribbean, and analyze their distribution patterns through a geographic gradient and along a bathymetric range. The results suggest that the boundaries of the local ecoregions may have to be reconsidered, which may have consequences for conservation strategies.

Yeemin et al. (2013) report on a long-term decline in Acropora species (Acroporidae) at Kut Island, eastern Gulf of Thailand, in relation to coral bleaching events in 1998 and 2010. The studied reef sites showed a reduction in live coral cover of 80-90\% following the 1998 bleaching event. Recruitment of juvenile Acropora colonies remained low. Since 2010, several Acropora species seem to be at risk for local extinction or may already have disappeared. Chavanich et al. (2013) report on the diversity and occurrence of nudibranchs in Thailand. The highest diversity, based on a 10-year survey, was recorded for the Andaman Sea (adjacent to the Indian Ocean), when compared with the Gulf of Thailand (bordering with the South China Sea under Pacific Ocean influence).

Waheed and Hoeksema (2013) studied species richness patterns of reef corals (Agariciidae, Euphylliidae, Fungiidae) around the Semporna peninsula in Malaysia. This area is known for its high coral diversity. Two main species clusters can be discerned, which reflects a difference in reef exposure with a gradient in increasing coral diversity from the exposed barrier reef to the relatively sheltered nearshore reefs. For the same area, van der Meij and Hoeksema (2013) discus the distribution of gall crabs (Cryptochiridae) inhabiting mushroom corals (Fungiidae). High occupancy rates were almost equally distributed over the sheltered and exposed sites, whereas sites without gall crabs were wave-exposed and predominantly under the influence of disturbances, such as blast fishing or relatively high nutrient loads.
Kamezaki et al. (2013) studied the relationship between Symbiodinium and zooxanthellate zoanthid colonies along the west coast of Okinawa, Japan. They show that Zoanthus sansibaricus has some genetic variation in its symbiosis with Symbiodinium, potentially allowing the species to colonize different depths on the subtropical coral reef.

This small, but diverse, collection of papers is expected to add to our understanding of the biodiversity of corals reefs. We hope that this special issue stimulates the publication of more papers on coral reef biodiversity in Marine Biodiversity.

Acknowledgements We are grateful to the editor of Marine Biodiversity and the publisher for allowing us to compile contributions for this special issue on Biodiversity of Coral Reefs. We want to thank the organizing committee of the 2nd World Conference on Marine Biodiversity in Aberdeen (26-30 September 2011) for their support.

\section{References}

Aguilar C, Reimer JD (2010) Molecular phylogenetic hypotheses of Zoanthus species (Anthozoa: Hexacorallia) using RNA secondary structure of the internal transcribed spacer 2 (ITS2). Mar Biodiv 40:195-204

Aharonovich D, Benayahu Y (2012) Microstructure of octocoral sclerites for diagnosis of taxonomic features. Mar Biodiv 42:173-177

Ahmadia GN, Pezold FL, Smith DJ (2012) Cryptobenthic fish biodiversity and microhabitat use in healthy and degraded coral reefs in SE Sulawesi, Indonesia. Mar Biodiv 42:433-442

Alexander V, Miloslavich P, Yarincik K (2011) The census of marine life - evolution of worldwide marine biodiversity research. Mar Biodiv 41:545-554

Alvarado JJ (2011) Echinoderm diversity in the Caribbean Sea. Mar Biodiv 41:261-285

Appeltans W, Ahyong ST, Anderson G et al (2012) The magnitude of global marine species diversity. Curr Biol 22:1-14

Barnes DKA, Barnes RSK, Smith DJ, Rothery P, Coral \& Coastal Ecology of the Seychelles Research Programme (2009) Littoral biodiversity across scales in the Seychelles, Indian Ocean. Mar Biodiv 40:109-119

Bijma J, Boekschoten GJ (1985) Recent bryozoan reefs and stromatolite development in brackish inland, SW Netherlands. Senckenb Marit 17:163-185 
Bouchet P (2006) The magnitude of marine biodiversity. In: Duarte CM (ed) The exploration of marine biodiversity: scientific and technical challenges. Fundacion BBVA, Madrid, pp 31-64

Burukovsky RN (2000) Lysmata splendida sp. nov., a new species of shrimp from the Maldives (Crustacea: Decapoda: hippolytidae). Senckenb Marit 30:223-227

Cairns SD (2007) Deep-water corals: an overview with special reference to diversity and distribution of deep-water scleractinian corals. Bull Mar Sci 81:311-322

Cairns SD, Kitahara MV (2012) An illustrated key to the genera and subgenera of the Recent azooxanthellate Scleractinia (Cnidaria: Anthozoa), with an attached glossary. ZooKeys 227:1-47

Cairns SD, Hoeksema BW, Van der Land J (1999) List of extant stony corals. Atoll Res Bull 459:13-46

Camillo CG, Puce S, Bavestrello G (2011) Lytocarpia and Cladocarpus (Cnidaria: Hydrozoa, Aglaopheniidae) from the Bunaken National Marine Park (North Sulawesi, Indonesia). Mar Biodiv 41:517-536

Carpenter KE, Abrar M, Aeby G, et al (2008) One-third of reefbuilding corals face elevated extinction risk from climate change and local impacts. Science 321:560-563

Carranza A, Recoil AM, Kitahara M, Scarabino F, Ortega L, López G, Franco-Fraguas P, De Mello C, Acosta J, Fontan A (2012) Deepwater coral reefs from the Uruguayan outer shelf and slope. Mar Biodiv 42:411-414

Chavanich S, Viyakarn V, Sanpanich K, Harris LG (2013) Diversity and occurrence of nudibranchs in Thailand. Mar Biodiv 43:31-36

Costello MJ, Coll M, Danovaro R, Halpin P, Ojaveer H, Miloslavich P (2010) A census of marine biodiversity knowledge, resources, and future challenges. PLoS One 5(8):e12110

Costello MJ, Bouchet P, Boxshall G, Fauchald K, Gordon D, et al (2013) Global coordination and standardisation in marine biodiversity through the World Register of Marine Species (WoRMS) and related databases. PLoS One 8(1):e51629

Davies SW, Rahman M, Meyer E, Green EA, Buschiazzo E, Medina M, Matz MV (2013) Novel polymorphic microsatellite markers for population genetics of the endangered Caribbean star coral, Montastraea faveolata. Mar Biodiv. doi:10.1007/s12526-012-0133-4

Dullo WC, Hecht C (1990) Corallith growth on submarine alluvial fans. Senckenb Marit 22:77-86

Fabricius KE (1996) Ecosystem recovery after episodic disturbance: resilience of some coral reefs after Acanthaster outbreaks. Senckenb Marit 27:227-235

Fishelson L (1989) Bisexuality and pedogenesis in gobies (Gobiidae: Teleostei) and other fish, or why so many little fish in tropical seas? Senckenb Marit 20:147-169

García-Matucheski S, Muniain C (2011) Predation by the nudibranch Tritonia odhneri (Opisthobranchia: Tritoniidae) on octocorals from the South Atlantic Ocean. Mar Biodiv 41:287-297

Grasshoff M (1979) Zur bipolaren Verbreitung der Oktokoralle Paragorgia arborea (Cnidaria: Anthozoa: Scleraxonia). Senckenb Marit 11:115-137

Grasshoff M (1985) Die Gorgonaria und Antipatharia der Großen Meteor-Bank und der Josephine-Bank (Cnidaria: Anthozoa). Senckenb Marit 17:65-87

Grasshoff M (1989) Die Meerenge von Gibraltar als Faunen-Barriere: die Gorgonaria, Pennatularia und Antipatharia der BALGIMExpedition (Cnidaria: Anthozoa). Senckenb Marit 20:201-223

Grasshoff M, Zibrowius H (1983) Kalkkursten auf Achsen von Hornkorallen, rezent und fossill. Senckenb Marit 15:111-145

Grossowicz M, Benayahu Y (2012) Differential morphological features of two Dendronephthya soft coral species suggest differences in feeding niches. Mar Biodiv 42:65-72

Harrison MA, Smith SDA (2012) Cross-shelf variation in the structure of molluscan assemblages on shallow, rocky reefs in subtropical, eastern Australia. Mar Biodiv 42:203-216
Heiss GA, Dullo WC, Reijmer JJG (1993) Short- and long-term growth history of massive Porites sp. from Aqaba (Red Sea). Senckenb Marit 23:135-141

Heiss GA, Dullo WC, Joachimski MM, Reijmer JJG, Schuhmacher H (1999) Increased seasonality in the Gulf of Aqaba, Red Sea, recorded in the oxygen isotope record of a Porites lutea coral. Senckenb Marit 30:17-26

Hoeksema BW (2007) Delineation of the Indo-Malayan centre of maximum marine biodiversity: the Coral Triangle. In: Renema W (ed) Biogeography, time and place: distributions, barriers and islands. Springer, Dordrecht, pp 117-178

Hoeksema BW (2012) Extreme morphological plasticity enables a free mode of life in Favia gravida at Ascension Island (South Atlantic). Mar Biodiv 42:289-295

Hoeksema BW, Waheed Z (2012) It pays to have a big mouth: mushroom corals ingesting salps at Sabah, Malaysia. Mar Biodiv 42:297-302

Hoeksema BW, van der Land J, van der Meij SET, van Ofwegen LP, Reijnen BT, van Soest RWM, de Voogd NJ (2011) Unforeseen importance of historical collections as baselines to determine biotic change of coral reefs: the Saba Bank case. Mar Ecol $32: 135-141$

Hoeksema BW, van der Meij SET, Fransen CHJM (2012) The mushroom coral as a habitat. J Mar Biol Assoc UK 92:647-663

Hui M, Kochzius M, Leese F (2012) Isolation and characterisation of nine microsatellite markers in the boring giant clam (Tridacna crocea) and cross-amplification in five other tridacnid species. Mar Biodiv 42:285-287

Kamezaki M, Higa M, Hirose M, Suda S, Reimer JD (2013) Different zooxanthellae types in populations of the zoanthid Zoanthus sansibaricus along depth gradients in Okinawa, Japan. Mar Bio$\operatorname{div} 43: 61-70$

Kleemann KH (1986) Das bohren and wachstum von Gregariella (Bivalvia: Mytilacea) aus der Karibik und dem Ost-Pazifik. Senckenb Marit 18:187-209

Kleemann K (1990) Boring and growth in chemically boring bivalves from the Caribbean, Eastern Pacific and Australia's Great Barrier Reef. Senckenb Marit 22:101-154

Lawniczak A (1987) Les modalités de croissance de l'axe calcaire chez Corallium johnsoni. Senckenb Marit 19:149-161

Malcolm HA, Jordan A, Smith SDA (2010) Biogeographical and cross-shelf patterns of reef fish assemblages in a transition zone. Mar Biodiv 40:181-193

Miller K, Neil H, Tracey D (2009) Recent advances in deep-sea coral science and emerging links to conservation and management of deep-sea ecosystems. Mar Ecol Prog Ser 397:1-5

Miloslavich P, Klein E (2009) The World Conference on Marine Biodiversity: current global trends in marine biodiversity research. Mar Biodiv 40:147-152

Ohara T, Fujii T, Kawamura I, Mizuyama M, Montenegro J, Shikiba H, White KN, Reimer JD (2013) First record of a mesophotic Pachyseris foliosa reef from Japan. Mar Biodiv. doi:10.1007/s12526-012-0137-0

Paulay G (1997) Diversity and distribution of reef organisms. In: Birkeland CE (ed) Life and death of coral reefs. Chapman \& Hall, New York, pp 298-353

Reimer JD, Shah MR, Sinniger F, Yanagi K, Suda S (2010) Preliminary analyses of cultured Symbiodinium isolated from sand in the oceanic Ogasawara Islands, Japan. Mar Biodiv 40:237-247

Reimer JD, Ishikawa SA, Hirose M (2011) New records and molecular characterization of Acrozoanthus (Cnidaria: Anthozoa: Hexacorallia) and its endosymbionts (Symbiodinium spp.) from Taiwan. Mar Biodiv 41:313-323

Santodomingo N, Reyes J, Flórez P, Chacón-Gómez IC, van Ofwegen LP, Hoeksema BW (2013) Diversity and distribution of azooxanthellate corals in the Colombian Caribbean. Mar Biodiv 43:7-22 
Schäfer W (1969) Sarso, Modell der Biofazies-Sequenzen im Korallenriff-Bereich des Schelfs. Senckenb Marit 1:165-188

Schönberg CHL (2000) Bioeroding sponges common to the central Australian Great Barrier Reef: Descriptions of three new species, two new records, and additions to two previously described species. Senckenb Marit 30:161-221

Schönberg CHL (2001) Estimating the extent of endolithic tissue of a Great Barrier Reef clionid sponge. Senckenb Marit 31:29-39

Senn DG, Glasstetter M (1989) On the occurrence of barnacle-reefs around Cocos-Island, Costa Rica. Senckenb Marit 20:241-249

Shenkar N (2012) Ascidian (Chordata, Ascidiacea) diversity in the Red Sea. Mar Biodiv 42:459-469

Stella JS, Pratchett MS, Hutchings PA, Jones GP (2011) Coralassociated invertebrates: diversity, ecology importance and vulnerability to disturbance. Oceanogr Mar Biol Annu Rev 49:43104

Türkay M, Schuhmacher H (1985) Latopilumnus tubicolus n. gen. n. sp., eine neue Korallen assoziierte Krabbe, die die Bildung einer wohnhöhle induziert (Crustacea: Decapoda: Pilumnidae). Senckenb Marit 17:55-63

Uiblein F, Christian Köhler C, Tian MC (1998) Quantitative examination of morphological variability among goatfishes of the genus
Upeneus from the Malayan province (Pisces: Perciformes: Mullidae). Senckenb Marit 28:123-132

Van der Meij SET, Hoeksema BW (2013) Distribution of gall crabs inhabiting mushroom corals on Semporna reefs, Malaysia. Mar Biodiv 43:53-59

Van der Meij SET, Reijnen BT (2012) First observations of attempted nudibranch predation by sea anemones. Mar Biodiv 41:281-283

Van der Meij SET, Suharsono, Hoeksema BW (2010) Long-term changes in coral assemblages under natural and anthropogenic stress in Jakarta Bay (1920-2005). Mar Pollut Bull 60:1442-1454

Waheed Z, Hoeksema BW (2013) A tale of two winds: species richness patterns of reef corals around the Semporna peninsula, Malaysia. Mar Biodiv 43:37-51

White KN (2012) Seasonal variation in sub-tropical Leucothoidae (Crustacea: Amphipoda) on Okinawa-jima, Japan. Mar Biodiv 42:453-457

White KN (2013) All things in moderation: using formalin to coerce leucothoid amphipods out of the rubble (Crustacea: Amphipoda: Leucothoidae). Mar Biodiv. doi:10.1007/s12526-012-0126-3

Yeemin T, Pengsakun S, Yucharoen M, Klinthong W, Sangmanee K, Sutthacheep M (2013) Long-term decline in Acropora species at Kut Island, Thailand, in relation to coral bleaching events. Mar Biodiv 43:23-29 